\title{
In-vitro predatory activity of nematophagous fungi from Costa Rica with potential use for controlling sheep and goat parasitic nematodes
}

\author{
Natalia Soto-Barrientos ${ }^{1}$, Jaqueline de Oliveira ${ }^{1}$, Rommel Vega-Obando ${ }^{2}$, Danilo Montero- \\ Caballero $^{3}$, Bernardo Vargas ${ }^{4}$, Jorge Hernández-Gamboa ${ }^{1} \&$ Claudio Orozco-Solano ${ }^{2}$ \\ 1. Cátedra de Parasitología y Enfermedades Parasitarias, Escuela de Medicina Veterinaria, Universidad Nacional, \\ Heredia, Costa Rica; nsotob@gmail.com, bianque01@yahoo.com.br, jorgeh@medvet.una.ac.cr \\ 2. Centro Nacional Especializado en Agricultura Orgánica, Instituto Nacional de Aprendizaje, Cartago, Costa Rica; \\ rvegaobando@ina.ac.cr, corozcosolano@ina.ac.cr \\ 3. Cátedra Salud de Hato, Escuela de Medicina Veterinaria, Universidad Nacional, Heredia, Costa Rica; \\ dmonterocaballero@hotmail.com \\ 4. Programa de Posgrado en Ciencias Veterinarias Tropicales, Escuela de Medicina Veterinaria, Universidad Nacional, \\ Heredia, Costa Rica; bvargas@medvet.una.ac.cr
}

\author{
Received 25-I-2010. C Corrected 18-VII-2010. Accepted 20-VIII-2010.
}

\begin{abstract}
In tropical and subtropical regions of the world, parasitic diseases are a main cause of losses in livestock productivity. The increased acquired resistence to anthelmintics by gastrointestinal nematodes, requires biological control be considered as a potential feasible and effective alternative. The most effective natural soil enemies of nematodes are nematophagous fungi. In order to collect and identify predator nematophagous fungi (PNF), samples were obtained from 51 farms distributed throughout the seven provinces of Costa Rica. The origin samples included: soil from different crops (potatoes, tomatoes, bananas, ornamental plants, squash and coffee); animal feces (cattle, sheep, goat and horse); soil and fallen leaves from forest; and plants with signs of nematode infection. Each sample was processed using three techniques for the extraction of fungi from soil: sprinkling technique, soil dilution and humidity chamber. Twenty four strains of nematophagous fungi were found in 19 farms; $83.3 \%$ of the fungi were isolated by sprinkling technique. The following fungi were idenified: Arthrobotrys oligospora $(\mathrm{n}=13)$; Candelabrella musiformis $(\mathrm{n}=9)$; and for the first time there was isolation of A. conoides $(\mathrm{n}=1)$ and A. dactyloides $(\mathrm{n}=1)$ in the country. Moreover, 16 strains from Trichoderma $(\mathrm{n}=13)$, Beauveria $(\mathrm{n}=1)$, Clonostachys $(\mathrm{n}=1)$ and Lecanicillium $(\mathrm{n}=1)$ were obtained. In addition, $\mathrm{pH}$ of each possible fungal isolation source was measured, and it varied from 5.2 to 9.9, however PNF isolates fell within the range of 5.6 to 7.5. The PNF strains were cultivated in four different media for the production of chhlamydospores: potato dextrose agar (PDA); corn meal agar (CMA); malt extract agar (MEA) and potato carrot agar (PCA). Out of these cultures, $95.8 \%$ of the strains formed chlamydospores primarily in the PCA. Of these strains, the profilic spore producers were subjected to ruminant artificial gastrointestinal conditions. A total of 14 fungi were tested, out of which $42.9 \%$ survived the digestive analysis. Neither A. conoides nor A. dactyloides were viable following the in vitro gastrointestinal test. The PNF isolated in this study demostrated an action against ovine and caprine gastrointestinal nematodes and are candidates for use in biological control of these organisms. Among these microorganisms, Candelabrella musiformis appears to be the most promising fungi for use as a biological control agent in Costa Rica. Rev. Biol. Trop. 59 (1): 37-52. Epub 2011 March 01.
\end{abstract}

Key words: predatory nematophagous fungi, Arthrobotrys spp., Candelabrella musiformis, chlamydospores.

In livestock production systems located in tropical and subtropical regions of the world, parasitic diseases have emerge as a major cause of losses in livestock productivity due to increased morbidity and mortality of the animals, reduced levels of production and productivity, reproductive disorders and high controls cost, among others (FAO 2003, Minglian 
et al. 2004, Araújo et al. 2006, Su et al. 2007). Gastrointestinal nematodes (GIN) in small ruminants include Haemonchus contortus, Telodorsagia circumcincta, Trichostrongylus spp., Nematodirus spp. and Cooperia spp. The proportion of each of these nematodes in small ruminants populations varies according to their geographical location; the highest prevalence exists in tropical humid areas, given that these conditions favor the development of eggs and larval states throughout the year (Chandrawathani 2004, Fleming et al. 2006). Due to the damage caused by the organisms, producers have been forced to invest significant resources trying to minimize the negative impact in their herds. For this reason, anthelmintics are highly utilized, often as the only strategy for the control of GIN, which has resulted in the development of antihelmintic resistance (FAO 2003, Fleming et al. 2006, Vargas 2006, Varady et al. 2007).

Given the acquired resistance by GIN to anthelmintics, biological control appears to be a feasible and effective alternative (Vargas 2006). One of the main natural enemies of nematodes in the soil are the nemathophagous fungi, which can be identified from soil samples and other substrates like domestic animal feces. These fungi are classified into four main groups: endoparasitic, opportunistic, toxic and predatory (Duddington 1955, Barron 1977, Minglian et al. 2004, Li et al. 2005, Su et al. 2007). Many of these fungi have been investigated worldwide, especially Arthrobotrys oligospora, Monacrosporium spp. and Duddingtonia flagrans (Larsen 2000).

This study seeks to determine the potential of Costa Rican strains of nematophagous fungi as an effective tool for GIN control in sheep and goat population in the country.

\section{MATERIALS AND METHODS}

Samples: Samples were taken from 51 different farms throughout the provinces of Costa Rica, distributed as follows: 12 in Alajuela, 17 in Cartago, 2 in Guanacaste, 2 in Heredia, 7 in Limón, 3 in Puntarenas and 8 in San José (Tables 1-2).

The nature of the samples included soils of different crops (potatoes, tomatoes, banana, ornamentals, squash and coffee), animal feces (cattle, sheep, goats and horses), soil, dead forest leaves and plants with signs of illness caused by nematodes (Table 3). Collected samples were placed into plastic bags properly labeled with the date, elevation, and

TABLE 1

Number of farms sampled according to altitude

\begin{tabular}{|cc|}
\hline Altitude (m.a.s.l.) & Number of farms sampled \\
$0-500$ & 17 \\
$501-1000$ & 5 \\
$1001-1500$ & 10 \\
$1501-2000$ & 12 \\
$2001-2500$ & 3 \\
$2501-3000$ & 1 \\
$>3000$ & 3 \\
\hline
\end{tabular}

TABLE 2

Number of farms sampled according to life zone

$\begin{array}{lc}\text { Life zones* } & \begin{array}{c}\text { Number of } \\ \text { farms sampled }\end{array} \\ \text { Tropical dry forest } & 1 \\ \text { Premontane moist forest } & 7 \\ \text { Lower montane moist forest } & 4 \\ \text { Tropical moist forest } & 3 \\ \text { Premontane moist forest, basal belt transition } & 1 \\ \text { Tropical moist forest, premontane belt transition } & 1 \\ \text { Tropical moist forest, perhumid transition } & 1 \\ \text { Lower montane wet forest } & 10 \\ \text { Premontane wet forest } & 7 \\ \text { Premontane wet forest, basal belt transition } & 7 \\ \text { Tropical wet forest } & 1 \\ \text { Premontane wet forest, rainforest transition } & 1 \\ \text { Montane wet forest } & 1 \\ \text { Tropical wet forest, premontane transition } & 1 \\ \text { Montane rainforest } & 2 \\ \text { Lower montane rainforest } & 2 \\ \text { Premontane rainforest } & 1\end{array}$

*according to L.R. Holdrige (Bolaños et al. 2005). 
TABLE 3

Origin of samples and code

\begin{tabular}{|c|c|c|}
\hline Origin & Sample type & Code \\
\hline Alajuela, San Carlos, Cedral, Finca Los Vega & Soil and pasture from equine faeces & $\mathrm{ECe}$ \\
\hline $\begin{array}{l}\text { Alajuela, Grecia, Cariblanco, Refugio Nacional de Vida Silvestre } \\
\text { Bosque Alegre, Laguna Hule }\end{array}$ & Soil and fallen leaves & $\mathrm{SCaB}$ \\
\hline Alajuela, Los Chiles & Farm soil without management & SCh1 \\
\hline Alajuela, Los Chiles & Farm soil without management & SCh2 \\
\hline Alajuela, San Carlos, Aguas Zarcas & Pasture soil and dairy cow feces & VAZ \\
\hline Alajuela, Sabanilla, Fraijanes, Finca La Rosalia & Pasture soil and dairy cow feces & $\mathrm{VF}$ \\
\hline Alajuela, San Carlos, Pital, Finca La Josefina & Pasture soil, sheep and dairy cow feces & VOJ \\
\hline Alajuela, Poas, San Juan Norte, Finca La Vistada & Pasture soil and dairy cow feces & VLV \\
\hline Alajuela, San Carlos, Monterrey & Pasture soil and dairy cow feces & VM \\
\hline Alajuela, Naranjo & Pasture soil and dairy cow feces & $\mathrm{VN}$ \\
\hline Alajuela, Poas, Finca La Rosela & Pasture soil and dairy cow feces & VPo1 \\
\hline Alajuela, Poas, Finca La Carmela & Pasture soil and dairy cow feces & VPo2 \\
\hline Cartago, Finca La Flor & Pasture soil and dairy goat feces & $\mathrm{CF}$ \\
\hline Cartago, Turrialba, Juan Viñas, Finca Ricardo Flores & Pasture soil and dairy goat feces & CJV \\
\hline Cartago, Oreamuno, Cipreses, Finca Los Cipreses & Pasture soil and dairy goat feces & COr \\
\hline Cartago, faldas del volcán Irazú, antiguamente finca lechera & Nematode diseased potato & $\mathrm{PC}$ \\
\hline Cartago, Oreamuno, La Chinchilla, CNEAO-INA & Soil and fallen leaves from forest & SBI \\
\hline Cartago, Turrialba, Santa Cruz & Coffee soil & SCT \\
\hline Cartago, Paraíso, Orosi & Ornamental plant soil & SOC \\
\hline Cartago, Oreamuno, Parque Nacional Volcán Irazú & Soil and fallen leaves from forest & SVI \\
\hline Cartago & Nematode infected tomato & $\mathrm{TC}$ \\
\hline Cartago, Alvarado, Capellades & Pasture soil and dairy cow feces & VAl \\
\hline Cartago, Finca Cabeza Vaca & Pasture soil and dairy cow feces & $\mathrm{VCV}$ \\
\hline Cartago, Llano Grande, Hacienda Retes & Pasture soil and dairy cow feces & VELG \\
\hline Cartago, Oreamuno, Paso Ancho, Finca La Cuesta & Pasture soil and dairy cow feces & VO \\
\hline Cartago, Alvarado, Pacayas & Pasture soil and dairy cow feces & $\mathrm{VPa}$ \\
\hline Cartago, Finca Santa Rosa & Pasture soil and dairy cow feces & VSR \\
\hline Cartago, Turrialba, Santa Cruz & Pasture soil and dairy cow feces & VT1 \\
\hline Cartago, Turrialba & Pasture soil and dairy cow feces & VT2 \\
\hline Guanacaste, Cañas, Finca Rio Lajas & Pasture soil and feces of sheep and goats & OCC \\
\hline Guanacaste, Cañas & Soil and feces of fattening cattle pasture & $\mathrm{VCa}$ \\
\hline Heredia, Barreal, UNA - Escuela de Medicina Veterinaria & Soil and pasture from equine y caprine feces & ECMV \\
\hline Heredia, Barva, Santa Lucia, Finca Experimental de la UNA & $\begin{array}{l}\text { Vermicompost, soil from mulberry plantation and } \\
\text { feces of dairy cows and sheep }\end{array}$ & VOSL \\
\hline Limón, Talamanca, Amubri & Soil and pasture from equine feces & ET \\
\hline Limón & Banana soil & SBL1 \\
\hline Limón & Banana soil & SBL2 \\
\hline Limón, Siquirres, Cimarrones & Farm soil without management & SCiL \\
\hline Limón, Siquirres, Cerro Siquirres & Farm soil without management & SCS \\
\hline Limón, Siquirres, La Francia & Farm soil without management & SFL \\
\hline Limón, Guápiles & Farm soil with organic management & SG \\
\hline Puntarenas, Buenos Aires, Biolley, Parque Internacional La Amistad & Soil and fallen leaves from forest & SAPt \\
\hline Puntarenas, Montes de Oro, Miramar & Farm soil without management & SM \\
\hline
\end{tabular}


TABLE 3 (Continued)

Origin of samples and code

\begin{tabular}{llc}
\multicolumn{1}{c}{ Origin } & \multicolumn{1}{c}{ Sample type } & Code \\
Puntarenas, Puerto Jimenez & Farm soil without management & SZS \\
San José, Uruca, INA & Soil and feces from goats & CINA \\
San José, Zona de los Santos, Parque Nacional Los Quetzales & Soil and fallen leaves from forest & SPQ \\
San José, Dota, Santa María & Coffee soil & SD \\
San José, Tarbaca & Farm soil without management & STa \\
San José, Sabanilla, Instalaciones deportivas de la UCR & Soil and fallen leaves from forest & SUCRD \\
San José, Zapote & Squash soil & SZa \\
San José, Coronado & Pasture soil and dairy cow feces & VCo \\
San José, Rancho Redondo, Finca La Socola & Pasture soil and dairy cow feces & VSo
\end{tabular}

geographical coordinates (as provided by a global positioning system) and were then taken to the Phytoprotection Laboratory of the Specialized National Center of Organic Agriculture, where they were held under refrigeration until processed.

Nematode larvae: GIN suspensions were used to stimulate the production of traps in the isolates, in slide culture for taxonomic identification, in the predation assay and in the viability assay. The GIN larvae were obtained from animals naturally infected by means of the fecal culture technique (Zajac \& Conboy 2006). Mixed cultures of infective larvae (L3) of Haemonchus contortus and Cooperia spp. ( $90 \%$ and $10 \%$ respectively), were used for the isolation, slide culture and viability tests. For the predation assay, the suspension used corresponded to $100 \%$ infective larvae of $H$. contortus.

Isolates: In the laboratory, samples were processed using three different techniques to extract fungi from soil: sprinkled (Barron 1977), soil dilution (Villalba 2006) and moist chamber (Delgado et al. 2001).

For the sprinkling method, the plates were placed in an incubator with an average temperature of $28^{\circ} \mathrm{C}, 80 \%$ humidity and artificial light. The material was checked on a daily basis from the fifth day with a stereoscope. As soon as the presence of trapped nematodes was identified, the fungus was isolated and purified.

In the soil dilution, $0.5 \mathrm{ml}$ of the solutions $(1: 10,1: 100$ and 1:1000) were cultivated in triplicate over selective media and placed on Petri dishes in advance. Potato-dextrose-agar (PDA Difco) with antibiotic (Oxoid Chloramphenicol selective supplement), acid PDA (1ml of citric acid at $10 \%$ per every $100 \mathrm{ml}$ of culture medium) and Rose Bengal (Oxoid Rose-Bengal Chloramphenicol Agar+Oxoid Chroramphenicol selective supplement) were used.

Plates were held in an incubator with an average temperature of $28^{\circ} \mathrm{C}, 80 \%$ humidity and artificial light. Cultures were examined 72 hours after planting; the growing colonies were analyzed under the microscope (at 40X) and those that showed conidia and mycelium similar to those described for PNF were purified.

Vessels with humidity chambers were kept for 15 days in a room at $27-29^{\circ} \mathrm{C}, 75-80 \%$ humidity and provided 12 hours of artificial light. The plates were monitored on a daily basis in order to observe mycelium development. The mature fungi were examined under a microscope at 40X. Those with conidia and mycelium similar to those described for PNF were purified (Orozco 2005).

For isolated fungi purification, conidia were collected with an inoculation loop and transferred to PDA with antibiotic (PDAatb) in order to eliminate bacteria. Then, conidia were 
transferred to acid PDA (PDAac) to facilitate the growth of contaminant saprophytic fungi. After achieving cleansing of PNF, isolates were transferred to PDA for storage.

Taxonomic identification: For taxonomic identification, the slide culture technique was used (Orozco 2005). The slides were observed under a microscope in order to identify characteristics and size of each conidia. According to shape and disposition of spores, the genus and species were identified using identification keys (Delgado et al. 2001).

pH of samples: The $\mathrm{pH}$ value was determined in each soil sampling.

Predation assay: All isolated strains were evaluated on capture percentages. Conidia were cultivated in water-agar (WA) plates, and 96 hours after fungus cultivation, they were added a suspension of approximately 100 GIN (six replicates per strain plus two controls using only larvae to evaluate if there was any contaminant nematophagous fungi) (Park et al. 2002, Araújo et al. 2004, González et al. 2005, Elósegui 2006). Plates were then incubated at $28^{\circ} \mathrm{C}, 80 \%$ humidity with artificial light. After 40 hours of incubation larvae were classified into the following four categories: trapped (those fixed or in motion that were in contact with traps), free (those moving continuously all over the plate), coiled (curled, immobile) and dead (those that were rigid, in a straight position and not in contact with traps) were counted and individually observed under the stereoscope. The trapped larvae percentage of the total counted larvae was calculated through an equation used by González et al. (2005).

Chlamydospore production: Cultures were performed with isolated fungi in four different agar media: Potato Dextrose Agar (PDA), Corn Meal Agar (CMA), Potato-Carrot Agar (PCA) and Malt Extract Agar (MEA). These cultures were incubated for 7 days at $28^{\circ} \mathrm{C}, 50 \%$ humidity and artificial light. Plates were then held at room temperature and in darkness for 6 to 8 weeks. Cultures positive for chlamydospores production were placed into suspensions using the Ojeda et al. (2005) technique. In order to evaluate the production of chlamydospores for each isolated fungus, another own methodology was applied: a small sample from the center of cultures of six weeks of age was taken and examined under the microscope. The following criteria were used:

- $\quad$ No chlamydospores were observed.

$+\quad$ A total of 1 to 5 chlamydospores on the slide, and they were hard to find.

++ Easy to find chlamydospores; however, there were not too many.

+++ There were plenty of chlamydospores, some were even forming chains.

Digestibility assay: The samples were taken to the Animal Food Science Laboratory at the University of Costa Rica, where in vitro digestibility assays described by Tilly \& Terry (1963) were performed under respective modifications regarding the substitution of fodder for chlamydospores (Orozco 2005). This assay was performed on fungi strains that formed the largest number of chlamydospores; in addition, the assay was performed on the $A$. conoides strain, which this has been reported as an acceptable candidate for $\mathrm{BC}$.

Viability assay: This test was performed to determine if any chlamydospore had survived the in vitro digestibility assay. This determination was made by a conidia germination test: chlamydospore reference samples that had been subjected to the artificial digestive process were plated onto Petri dishes containing WA, a suspension of GIN was then added (Park et al. 2002, Araújo et al. 2004, González et al. 2005, Elósegui 2006).

The statistical analysis included a comparison of the variables using the non-parametric Kruskal Wallis-test, based on a qualitative scale. Data analysis was performed using Infostat (2002). The statistical significance of the variables was tested at a 0.05 level of significance. 


\section{RESULTS}

Fungal isolation: From the 51 sampled farms, 24 PNF of the Arthrobotrys and Candelabrella genera were isolated (Table 4). Additionally, 1 strain of Beauveria sp., 1 of Clonostachys sp., 1 of Lecanicillium sp., and 13 strains of Trichoderma sp were isolated.

From the isolated PNF, 20 were obtained by the soil sprinkling technique $(\mathrm{p}<0.001) v s .2$ by soil dilution and 2 by the humidity chamber. Strains of Beauveria sp., Clonostachys sp., Lecanicillium sp. and Trichoderma sp. were isolated by the soil dilution technique.

Taxonomic identification: Of the isolated PNF, 13 were identified as Arthrobotrys oligospora, 1 as A. conoides, 1 as A. dactyloides and 9 as Candelabrella musiformis.

TABLE 4

$\mathrm{pH}$ of the fungal isolate source and number of fungi isolated by province, altitude and life zone

\begin{tabular}{|c|c|c|c|c|c|}
\hline & & \multicolumn{4}{|c|}{ Fungi } \\
\hline & & $\begin{array}{c}\text { Arthrobotrys } \\
\text { conoides }\end{array}$ & $\begin{array}{c}\text { Arthrobotrys } \\
\text { dactyloides }\end{array}$ & $\begin{array}{c}\text { Arthrobotrys } \\
\text { oligospora }\end{array}$ & $\begin{array}{c}\text { Candelabrella } \\
\text { musiformis }\end{array}$ \\
\hline \multirow[t]{3}{*}{$\mathrm{pH}$} & Least & $5.6(\mathrm{SD})$ & $7.1(\mathrm{SZa})$ & $5.6(\mathrm{SD})$ & $5.9(\mathrm{SCT})$ \\
\hline & Maximum & $5.6(\mathrm{SD})$ & $7.1(\mathrm{SZa})$ & 7.5 (SFL) & $7.6(\mathrm{SM})$ \\
\hline & Average & $5.6(\mathrm{SD})$ & $7.1(\mathrm{SZa})$ & 6.6 & 6.7 \\
\hline \multirow[t]{7}{*}{ Province } & Alajuela & 0 & 0 & 1 & 1 \\
\hline & Cartago & 0 & 0 & 5 & 2 \\
\hline & Guanacaste & 0 & 0 & 0 & 0 \\
\hline & Heredia & 0 & 0 & 4 & 1 \\
\hline & Limón & 0 & 0 & 1 & 3 \\
\hline & Puntarenas & 0 & 0 & 0 & 2 \\
\hline & San José & 1 & 1 & 2 & 0 \\
\hline \multirow{7}{*}{$\begin{array}{l}\text { Altitude } \\
\text { (m.a.s.1.) }\end{array}$} & $0-500$ & 0 & 0 & 1 & 5 \\
\hline & $501-1000$ & 0 & 0 & 1 & 1 \\
\hline & $1001-1500$ & 0 & 1 & 5 & 1 \\
\hline & $1501-2000$ & 1 & 0 & 4 & 1 \\
\hline & $2001-2500$ & 0 & 0 & 0 & 1 \\
\hline & $2501-3000$ & 0 & 0 & 1 & 0 \\
\hline & $>3000$ & 0 & 0 & 1 & 0 \\
\hline \multirow[t]{10}{*}{ Life zone* } & Premontane moist forest & 0 & 1 & 1 & 5 \\
\hline & Lower montane moist forest & 0 & 0 & 0 & 2 \\
\hline & Tropical moist forest & 0 & 0 & 2 & 0 \\
\hline & Lower montane wet forest & 1 & 0 & 1 & 2 \\
\hline & Premontane wet forest & 0 & 0 & 1 & 0 \\
\hline & Premontane wet forest, basal belt transition & 0 & 0 & 2 & 1 \\
\hline & Premontane wet forest, rainforest transition & 0 & 0 & 1 & 0 \\
\hline & Montane wet forest & 0 & 0 & 0 & 1 \\
\hline & Montane rainforest & 0 & 0 & 0 & 1 \\
\hline & Lower montane rainforest & 0 & 0 & 1 & 1 \\
\hline
\end{tabular}

*according to L.R. Holdrige (Bolaños et al. 2005). 
pH of samples: The $\mathrm{pH}$ level of the samples fell within a wide range; the most acidic was 5.2 (SCh1), while the most alkaline was of 9.9 (VELG), creating an average of 7.8. In soils from which PNF were isolated, the lowest $\mathrm{pH}$ was 5.6 (SD) and the highest 7.5 (SFL) (Fig. 1).

The following strains showed an extremely slow growth in PDAac: SZa (A. dactyloides; pH 7.1), SM (C. musiformis; pH 7.6), SFL (A. oligospora; $\mathrm{pH} 7.5$ ) and VLV (A. oligospora; pH 6.7).

Predation Assay: The strain that demonstrated the highest predacious ability was SAPt
(C. musiformis) with $96.6 \%$, while the one that showed the lowest capture percentage was TC (A. oligospora) with $9.1 \%$ (Fig. 2).

Capture percentage of the A. oligospora strains varied widely between $9.1 \%$ in the TC strain and $93.4 \%$ in the VSL strain, with an average capture ability of $68.7 \%$ (Fig. 2). The predacious capability of $C$. musiformis strains was otherwise more homogeneous, with a smaller range that varied from $70.8 \%$ of SCT strain to $96.6 \%$ of SAPt strain and a capture average of $86.1 \%$.

Since just one strain of $A$. conoides (64.9\%) and one of A. dactyloides (89.7\%)

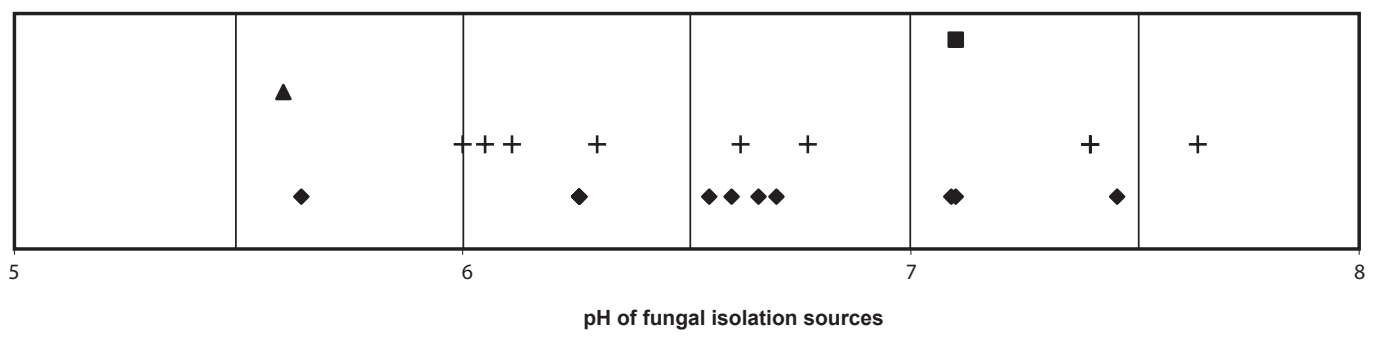

- Arthrobotrys oligospora

- Arthrobotrys conoides

- Arthrobotrys dactyloides

Fig. 1. $\mathrm{pH}$ of soils where predatory nematophagous fungi were isolated.

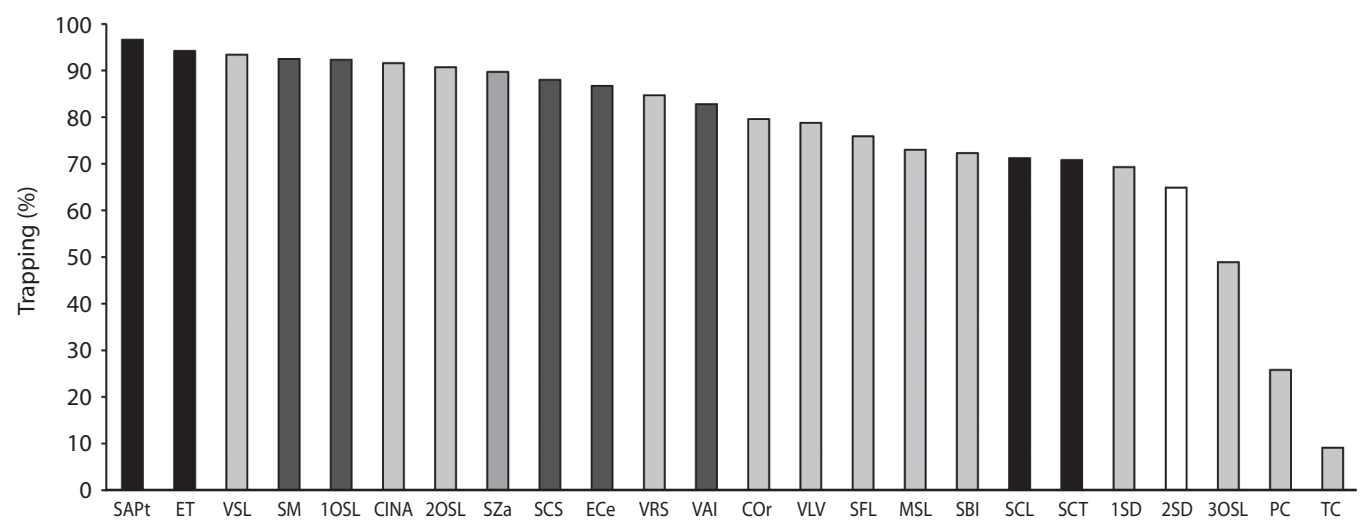

- Candelabrella musiformis $\square$ Arthrobotrys dactyloides $\quad$ Arthrobotrys oligospora $\square$ Arthrobotrys conoides

Fig. 2. In vitro trapping percentages of the predatory nematophagous fungi isolated, against infective larvae (L3) of Haemonchus contortus. $*$ Six replicates per strain +2 controls using only larvae to evaluate if there was any contaminant nematophagous fungi. 
were isolated, it was not possible to carry out comparisons among different strains.

The controls containing only larvae had a mortality rate of $1.6 \%$ and $4 \%$ of coiled larvae.

Despite the wide range of predation rates, statistical analysis showed no significant differences between the average catch $(p=0.25)$.

Production of chlamydospores: Out of 24 isolated PNF, 23 were positive for the formation of resistance structures (Figs. 3-4). Only the TC (A. oligospora) strain did not produce them.

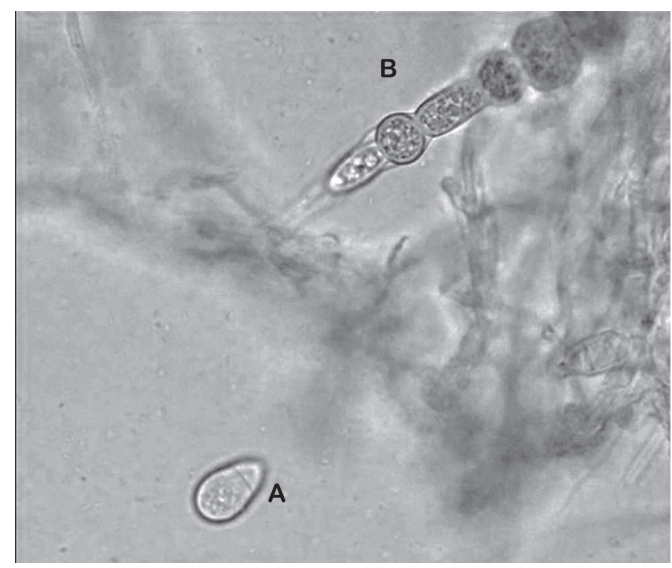

Generally, C. musiformis strains showed a higher production of chlamydospores than Arthrobotrys genus strains (Table 5); however, statistical analysis showed no significant differences $(\mathrm{p}=0.10)$ among the four species.

Regarding culture media, PCA was the most effective, followed by PDA, CMA (most effective for conidia formation) and MEA $(\mathrm{p}<0.01)$. On MEA media, fungi presented highly dispersed micelial growth and exhibited very limited chlamydospore and conidia formation (Table 5).

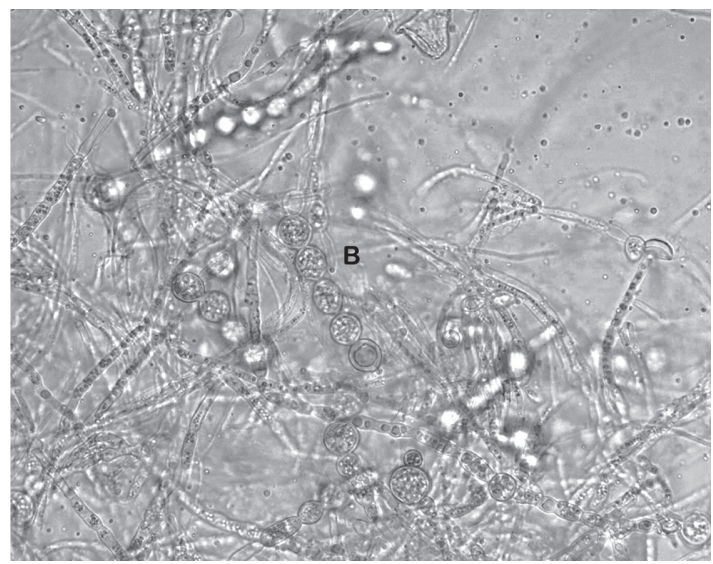

Fig. 3. (A) Conidia from Athrobotrys oligospora; (B) Chlamydospore chains formed by Arthrobotrys oligospora.

Viability assay: Out of 13 fungi that underwent the in vitro digestibility assay, 6 were positive for growth in WA plates added with larvae. Of these fungi, three corresponded to the $C$. musiformis species (ET, SCS, SM) and the other three to A. oligospora (VLV, COr, SBI) (Table 6).

\section{DISCUSSION}

Isolates and taxonomic identification: It was expected that most of PNF could be isolated using the soil sprinkling technique described by Barron (1977). Nevertheless, the use of other techniques favored and accelerated the growth of saprophyte fungi such as Rhizopus, Fusarium, Phoma, Aspergillus and Penicillium,

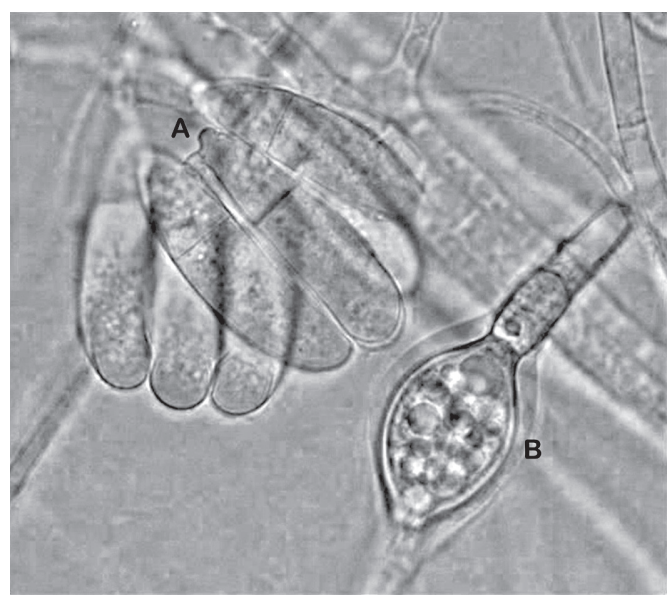

Fig. 4. (A) Conidias from Candelabrella musiformis; (B) Single chlamydospore formed by Candelabrella musiformis. 
TABLE 5

Chlamydospores production by the predatory nematophagous fungi isolated ${ }^{l}$

\begin{tabular}{|c|c|c|c|c|c|}
\hline Code & Fungi & $\mathrm{CMA}^{2}$ & $\mathrm{PDA}^{2}$ & $\mathrm{PCA}^{2}$ & $\mathrm{MEA}^{2}$ \\
\hline $\mathrm{ECe}$ & C. musiformis & - & - & ++ & - \\
\hline VLV & A. oligospora & ++ & ++ & + & ++ \\
\hline COr & A. oligospora & + & ++ & + & ++ \\
\hline $\mathrm{PC}$ & A. oligospora & ++ & ++ & ++ & + \\
\hline SBI & A. oligospora & ++ & +++ & +++ & + \\
\hline SCT & C. musiformis & - & ++ & - & - \\
\hline $\mathrm{TC}$ & A. oligospora & - & - & - & - \\
\hline VAl & C. musiformis & +++ & +++ & +++ & - \\
\hline VSR & A. oligospora & - & ++ & +++ & ++ \\
\hline 1OSL & C. musiformis & + & ++ & +++ & + \\
\hline 2OSL & A. oligospora & - & - & + & - \\
\hline 3OSL & A. oligospora & - & - & ++ & - \\
\hline VSL & A. oligospora & + & + & + & - \\
\hline MSL & A. oligospora & ++ & + & - & - \\
\hline ET & C. musiformis & + & +++ & +++ & - \\
\hline $\mathrm{SCL}$ & C. musiformis & +++ & +++ & +++ & + \\
\hline SCS & C. musiformis & +++ & + & ++ & + \\
\hline SFL & A. oligospora & - & ++ & ++ & - \\
\hline SAPt & C. musiformis & ++ & + & - & - \\
\hline $\mathrm{SM}$ & C. musiformis & +++ & +++ & +++ & + \\
\hline CINA & A. oligospora & + & + & ++ & + \\
\hline $1 \mathrm{SD}$ & A. oligospora & - & - & +++ & - \\
\hline $2 \mathrm{SD}$ & A. conoides & + & - & - & + \\
\hline $\mathrm{SZa}$ & A. dactyloides & + & ++ & +++ & + \\
\hline
\end{tabular}

1. (-) no chlamydospores were observed; (+) indicated that there were 1 to 5 chlamydospores total in the sample taken and they were hard to find; $(++)$ it was easy to find chlamydospores, however, there were not too many; $(+++)$ there were plenty of chlamydospores; some were even forming chains..

2. $\mathrm{CMA}=$ corn-meal agar; $\mathrm{PDA}=$ potato-dextrose agar; $\mathrm{PCA}=$ potato-carrot agar; $\mathrm{MEA}=$ malt-extract agar.

TABLE 6

Summary data of the nematophagous fungi positive to the viability assay

\begin{tabular}{|c|c|c|c|c|c|c|}
\hline Code & Fungus & Origin & $\begin{array}{l}\text { Altitude } \\
\text { (m.a.s.1.) }\end{array}$ & Life $_{\text {zone }}{ }^{1}$ & $\mathrm{pH}$ & $\begin{array}{c}\text { Capture } \\
(\%)\end{array}$ \\
\hline VLV & A. oligospora & Poás, Alajuela & 2500 & Lower montane wet forest & 6.7 & 78.8 \\
\hline COr & A. oligospora & Oreamuno, Cartago & 1700 & Lower montane moist forest & 7.1 & 79.5 \\
\hline SBI & A. oligospora & La Chinchilla, Cartago & 1453 & Lower montane moist forest & 6.6 & 72.3 \\
\hline ET & C. musiformis & Talamanca, Limón & 90 & Tropical moist forest & 7.4 & 94.2 \\
\hline SCS & C. musiformis & Siquirres, Limón & 358 & $\begin{array}{l}\text { Premontane wet forest, basal } \\
\text { belt transition }\end{array}$ & 6.1 & 88 \\
\hline SM & C. musiformis & Miramar, Puntarenas & 340 & Tropical moist forest & 7.6 & 92.5 \\
\hline
\end{tabular}

1. according to L.R. Holdrige (Bolaños et al. 2005). 
since they are facultative saprophytic microorganisms. In addition, due to spacing, saprophyte fungi prevented the growth of PNF. Mota et al. (2003), states that some species of PNF develop traps as a result of external stimulus (physiological stress, presence of nematodes or their excreta), while others develop spontaneously and proved to be more dependant on nematodes as a source of nutrients. This explains why few PNF strains were obtained by using the soil dilution technique. In this technique, fungi are never stressed regarding the culture media (nutrients, humidity, time, etc.) and they are not stimulated with nematodes.

Growth of endoparasitic nematophagous fungi is even slower than that of predators, and the soil sprinkling technique proved ineffective in isolating them. Furthermore, another possible reason why endoparasitic nematophagous fungi were not isolated, is that PNFs have been reported to be more aggressive, quickly exhausting nutrient sources (nematodes), leaving others without media to grow and sporulate (Larsen 2000). Out of the purpose of this study, Barron (1977) described a Baermann funnel technique for the isolation of these fungi, but this methodology was not employed as we were interested in PNFs.

Conversely only PNF from plants with observed signs of nematode-induced disease could be isolated by the humidity chamber technique. According to Delgado et al. (2001) and Cabezas (2004), the purpose of this technique is to give favorable humidity conditions in order to reactivate and accelerate fungi growth in the sample.

When using soil and feces samples, certain structures similar to A. oligospora conidia were seen under the microscope, but when trying to isolate them, faster growing saprophyte fungi grew (mainly Fusarium and Aspergillus), possibly because they were more abundant than the PNFs. On the contrary, in the case of plants, there was a nematode population already established, providing the PNF with additional sources of nutrients, enabling them to colonize faster and more prolifically than other saprophytes.
The taxonomic identification of PNF was carried out based on the observation of fungi morphological characteristics presented when trapping nematodes, rather than in pure cultures where traps are usually non-existent. Furthermore, the dimensions of the conidia and the morphology of the conidiophore can be altered considerably (Cooke \& Godfrey 1964, Haard 1968, Van Oorschot 1985). The fungus with the highest number of isolates was A. oligospora, followed by $C$. musiformis, which was already expected. Barron (1977), states that fungi that form adhesive networks are ubiquitous and very aggressive and thus predominant in soil samples. He also mentions that A. oligospora is the most common isolated PNF, which coincides with Orozco's (2005) study of Costa Rican PNF. Orozco obtained a similar result in the isolation of these two species. In the aforementioned study, A. oligospora, C. musiformis and Dactyllela sp. were isolated. Contrary to Orozco's (2005) results, in this study Dactyllela sp. was not isolated and only one strain of A. conoides and A. dactyloides were isolated. The above-mentioned discrepancy could be due to two situations: 1 . human error: since the conidiophores of these fungi are similar to those of other fungi that grow in Petri dishes and they could have gone unnoticed; 2 . These Arthrobotrys and Dactyllela spp. species might be not as abundant in Costa Rica, making difficult to isolate them (Orozco 2005).

Regarding altitude and life zone, there is no similar information in the consulted literature in order to make comparisons. Nevertheless, it may be concluded that there is PNF presence at various altitudes and life zones, which reveals the versatility of these fungi.

pH in soils: $\mathrm{pH}$ and temperature are two key parameters for fungi growth manipulation, sporulation and saprophytic ability (Hajieghrari et al. 2008). Madigan et al. (2000) states that fungi, as a group, tend to tolerate more acid environments than bacteria and that most of them grow properly in a $\mathrm{pH}$ of 5.0 or lower. On the contrary, the PNF in this study were isolated mainly from soil $\mathrm{pH}$ of 6.0 to 7.5. Strains 
such as SZa (A. dactyloides; pH 7.1), SM (C. musiformis; $\mathrm{pH}$ 7.6), SFL (A. oligospora; $\mathrm{pH}$ 7.5) and VLV (A. oligospora; $\mathrm{pH}$ 6.6) showed an extremely slow growth in PDAac. However, PNF such as A. oligospora, C. musiformis, A. oviformis, Monacrosporum megalosporum and Dactylaria parvispora show an extracellular serine-protease, similar to subtilisine, responsible for the immobilization of trapped nematodes and impoverishing their cuticle to introduce hyphae (Tunlid \& Jansson 1991, Minglian et al. 2004, Kanda et al. 2008, Nagee et al. 2008). Acid $\mathrm{pH}$ affects the transcription of genes that codify said enzyme, its optimal $\mathrm{pH}$ activity is between 6.0 and 8.0 (Tunlid \& Jansson 1991, Kanda et al. 2008). The expression of this serine protease is related to the physiology and the pathogenicity of the PNF. If this enzyme is not produced, fungi cannot pass from their saprophytic phase to the predacious mode, and may even be non-viable, because a cuticle peptide is released by the nematodes as a reaction to the serine protease, which promotes the formation of traps (Åhman et al. 2002, Kanda et al. 2008).

Predation assay: The transformation of PNF from saprophytic to a pathogenic state is determined by the presence and the quantity of nematodes, as well as the nutritional conditions of the medium: as the amount negative affect on the predacious ability, there is an amount of nutrients increases, mainly in $A$. oligospora (Morgan et al. 1997). Due to this fact, the assay was performed in WA, and although the amount of nematodes affects the change from saprophytic to pathogenic state in a directly proportional way, it was considered that 100 was a relatively good amount of larvae and it facilitated the final count in the assay. This explains the high predacious percentage in the majority of the strains: in a medium where the nutrients are limited, nematodes become an important source of nitrogen for growth and providers of essential substances such as amino acids and vitamins (Morgan et al. 1997, González et al. 2005, Migunova \& Byzov 2005).
On the other hand, it was noticed that some strains (TC, PC, 3OSL, 1SD, COr and VAl) demonstrated a slow growth before the larvae were added. Park et al. (2002) gives a four-day period for incubation of fast growth fungi, and a seven-day period for the slow growing fungi. However, this methodology was not utilized, which could have influenced the low capture percentages in those strains. In this case, the added larvae were extracted from an ovine sample. Orozco (2005) reported that certain Costa Rican strains of A. oligospora and $C$. musiformis as well, showed differences in the percentage of trapping larvae depending on their origin. Thus, according to Orozco (2005), the A. oligospora strains showed a higher tendency to capture larvae of ovine nematode and presented a homogeneous predatory capability, while the $C$. musiformis strains preferred larvae of goat nematodes and their predacious ability was very heterogeneous. The results in this study differ from Orozco's (2005), since capture percentages of larvae of ovine nematodes by the $C$. musiformis strains were higher than the A. oligospora strains (which showed a more heterogeneous capture percentage); this result resembles what Park et al. (2002) described.

The differences reported by several researchers, indicate that the predacious abilities of the PNF species can vary according to the region and environmental factors where the strains are isolated (Graminha et al. 2005a). According to González et al. (2005), the temperature can affect the development of the traps in A. conoides and A. oligospora; consequently, it can affect the trapping percentage of fungi. In the case of A. oligospora strains, it was noticed that both strains coming from cold zones, and the ones from the hot zones showed very different capture percentages, so it cannot be stated that the change of temperature for this specie had an influence on the test. On the other hand, only one strain of A. conoides was found; therefore, no comparisons could be made. Given that this species is reported by many as an excellent predator, it is possible that the change in temperature between its natural environment and the laboratory's had affected the development 
of its traps and prevented obtaining results as good as those reported by Graminha et al. (2005a), of $99.3 \%$ nematode capture.

In the case of $A$. dactyloides, there is little information about the predacious capability regarding animal nematodes; according to Núñez (2002), this fungus is closely related to roots of plants. Consequently, they are in a favorable position for trapping phytoparasitic nematodes. In studies carried out with Meloidogyne incognita (a root-knot nematode of various plant species), a capture rate of up to $81.8 \%$ of juveniles is reported (Kumar \& Singh 2006), which is not far from the $89.7 \%$ obtained in the test done with larvae of sheep in this study. It was noted that the two strains with the lowest capture (TC and PC) were isolated from plants infected by nematodes. Gomes et al. (2000), states that free-living larvae are preferred by PNF above NGI of ruminants.

The only fungus isolated from ovine feces (C. musiformis 1OSL) had a good capture percentage; however, it was not as good as expected. The best three strains were isolated in places where there were no species of ovine: a national park, equine pastures and pastures for dairy cows. Araújo et al. (2006) indicates that PNF are not specific for a particular genus of nematodes of the same animal species.

Production of chlamydospores, digestibility and viability assays: Chlamydospores, resistance spores which survive in unfavorable environmental conditions, are found in many of the PNF. Their production is the result of different factors in the culture: incubation time, temperature and medium utilized (Park et al. 2002).

From the culture media used in this study, the PCA contained the lowest amount of digestible carbohydrates (Carris 2009); this would explain why the highest amounts of chlamydospores were formed in it. On the other hand, according to Carris (2009), the majority of fungi grow really well in PDA, but this medium can be very rich, and the excessive mycelia growth can affect sporulation. In this case, the stress factor could be the limited space in the Petri dish or the amount of nutrients: even though the medium is very rich, the growth of the fungus is extremely accelerated. In the case of MEA and CMA, these cultivation media are reported as weak media (as compared to PDA) that can be utilized for cultivation of soil fungi and that show a balance between the growth of mycelia and sporulation (Carris 2009).

During this research, the piece used to introduce humidity in the incubator for cultivating fungi broke down. In order to avoid delaying the project, vessels with distilled water were introduced into the chamber to provide humidity and continue with the cultivations. It was determined, using a hygrometer, that the humidity was held at 50\%; however, there was not enough space in the incubator for more vessels, for this reason, it was decided to work with that percentage of humidity. This variation in the humidity caused all incubated fungi in that moment to form chlamydospores, which presented a great opportunity to perform this assay.

In this study, $95.8 \%$ of the isolated strains formed chlamydospores (23 out of 24). This result was not expected; in the work done by Orozco (2005) with Costa Rican strains, only strains of species of $C$. musiformis produced a big quota of chlamydospores, while strains of species A. oligospora did not. Park et al. (2002) reports this last species as producers of resistance structures and mentions that fungi that grow under dry conditions are prone to survive due to the formation of chlamydospores. The count was established by means of plus signs (+) in order to determine the best strains according to production of chlamydospores.

Out of the 23 strains that form chlamydospores, 14 underwent the digestibility assay. Out of these 14 strains, 13 were chosen for their good performance regarding production of resistance spores and the remaining strain was chosen for being the only A. conoides one. Haard (1968) describes that in this species, chlamydospores are abundant in old cultures; however, this strain did not prove to be a good producer of spores of resistance. Instead, it was chosen for the digestibility assay. 
The six positive strains in the viability assay were divided between the A. oligospora and the $C$. musiformis species. Three of them (VLV, ET and COr) were isolated from pastures where the feces are frequently deposited. Animals then consume the spores along with the grass, as a result, these strains could even adapt to adverse conditions of the gastro-intestinal tract of animals, which can be interpreted as the positive result in the assay (Orozco 2005). A. conoides did not survive the digestibility assay; this coincides with Graminha et al. (2005b) who obtained the same results in his investigation of A. conoides and C. musiformis.

Regarding A. dactyloides, the strain that underwent the digestibility assay could not be re-isolated in the viability test. Unfortunately, there is no information in the literature consulted about survival of chlamydospores of this fungus species in similar assays in order to carry out any kind of comparison. Even so, Graminha et al. (2005b) indicates that chlamydospores might not survive due to the adverse conditions to which they were subjected, such as: acids, $\mathrm{pH}$, temperature or competition with micro biota.

Regardless of the obtained results, it is not recommended to reject the strains that did not survive the digestibility assay, since Flores et al. (2003) assures that in animals, fungi can be protected by intestinal content. It should be kept in mind that the intestinal content of the ruminants is rich in cellulose, a compound resistant to the action of gastric acids, which can become a key element in the protection of spores, preventing the acids from working directly on and degrading them. This type of protection does not exist for in vitro tests, thus the reaction mixture is in direct contact with fungi, favoring its easy degradation (Orozco 2005). Consequently, Araújo et al. (2006) considers that when choosing a PNF, one should take into account not only in vitro tests, but also field tests. When carrying out field tests, PNF species from the same locations where they will be applied should be favored for use in $\mathrm{BC}$ of parasites.
Among these microorganisms, Candelabrella musiformis, due to its easy isolation, good predatory capacity and ability to form chlamydospores in a humidity common in the country, appears to be the most promising fungi for use as a biological control agent in Costa Rica.

\section{ACKNOWLEDGMENTS}

We would like to thank Jorge Sánchez and Adrián Martínez, University of Costa Rica, for their collaboration during the digestibility assay. Miguel Obregón, who helped identifying fungi. The CNEAO-INA, especially to Carmen Durán and Efraín Muñoz, who provided financial support. Felipe Torres, Armando Aguilar, Iván Rodríguez, Ramón Cámara and Nadia Ojeda for inspiring and guiding this investigation.

\section{RESUMEN}

El control biológico es en la actualidad una alternativa para el control de los nematodos gastrointestinales que desarrollaron resistencia a los principales grupos de antihelmínticos. Para el aislamiento e identificación de hongos nematófagos depredadores, se tomaron muestras de 51 fincas distribuidas entre todas las provincias de Costa Rica. La naturaleza de las muestras incluyó: suelos de diferentes sembradíos (papa, tomate, banano, plantas ornamentales, chayote y café), heces de animales (bovinos, ovinos, caprinos y equinos), suelo y hojarasca de bosques y plantas con signos de enfermedad causada por nematodos. Las muestras se procesaron mediante 3 técnicas diferentes para la extracción de hongos a partir del suelo: espolvoreado en placa, dilución de suelos y cámara húmeda. Veinticuatro cepas de hongos nematófagos fueron aisladas de 19 fincas; el $83.3 \%$ de éstos fueron aislados mediante las técnica de espolvoreado en placa. Los hongos fueron identificados como: Arthrobotrys oligospora $(\mathrm{n}=13)$, Candelabrella musiformis $(\mathrm{n}=9)$ y por primera vez se reporta el aislamiento de $A$. conoides $(n=1)$ y A. dactyloides $(n=1)$ en el país. Asimismo, se aislaron 16 cepas de hongos de los géneros Trichoderma $(\mathrm{n}=13)$, Beauveria $(\mathrm{n}=1)$, Clonostachys $(\mathrm{n}=1)$ y Lecanicillium $(\mathrm{n}=1)$. Adicionalmente se les midió el $\mathrm{pH}$, el cual varió entre 5.2-9.9, ubicándose los HND dentro de un rango entre 5.6-7.5. Las cepas de HND fueron cultivadas en 4 medios diferentes para la producción de clamidosporas: papa dextrosa agar, harina de maíz, extracto de malta y agar papa-zanahoria. El $95.8 \%$ de las cepas aisladas produjeron clamidosporas, principalmente en el 
medio agar papa-zanahoria. De estas cepas, se escogieron las de mayor producción para ser sometidas a la prueba de digestibilidad in vitro. Un total de 14 cepas fueron sometidos a esta prueba, de las cuales el $42.9 \%$ resultaron viables; de éstas, las cepas de A. conoides y A. dactyloides no sobrevivieron a la prueba de digestibilidad in vitro. De los microorganismos aislados, Candelabrella musiformis se considera el más promisorio de los hongos como agente biológico en Costa Rica.

Palabras clave: hongos nematófagos depredadores, Arthrobotrys spp., Candelabrella musiformis, clamidosporas.

\section{REFERENCES}

Åhman, J., T. Johansson, M. Olsson, P.J. Punt, C.A.M.J.J. van den Hondel \& A. Tunlid. 2002. Improving the pathogenicity of a nematode-trapping fungus by genetic engineering of a subtilisin with nematotoxic activity. Appl. Environ. Microb. 68: 3408-3415.

Araújo, J.V., R.C.L. Assis, A.K. Campos \& M.A. Mota. 2004. Atividade in vitro dos fungus nematófagos dos gêneros Arthrobotrys, Duddingtonia e Monacrosporium sobre nematóides trichostrongilídeos (Nematoda: Trichostrongyloidea) parásitos gastrointestinais de bovinos. Rev. Bras. Parasitol. Vet. 13: 67-71.

Araújo, J.V., R.C.L. Assis, A.K. Campos \& M.A. Mota. 2006. Efeito antagônico de fungos predadores dos gêneros Monacrosporium, Arthrobotrys e Duddingtonia sobre larvas infectantes de Cooperia sp. e Oesophagostomum sp. Arq. Bras. Med. Vet. Zootec. 58: 373-380.

Barron, G.L. 1977. The nematode destroying fungi: topics in mycobiology, no. 1. Canadian Biological, Ontario, Canada.

Bolaños, R., V. Watson \& J. Tosi. 2005. Mapa ecológico de Costa Rica (Zonas de Vida, según el sistema de clasificación de zonas de vida del mundo de L.R. Holdridge). Escala 1:750 000. Centro Científico Tropical, San José, Costa Rica.

Carris, L. 2009. General mycology. (Downloaded: May 29, 2009, http://classes.plantpath.wsu.edu/plp521/).

Cabezas, O. 2004. Diagnóstico de enfermedades en plantas. (Downloaded: October 16, 2008, www.senasa. gob.pe/servicios/intranet/capacitacion/cursos/curso_ tingo_maria/diagnostico_enfermedades_plantas.pdf).

Chandrawathani, P. 2004. Problems in the control of nematode parasites of small ruminants in Malaysia: resistance to anthelmintics and the biological con- trol alternative. Ph.D thesis, Swedish University of Agricultural Sciences, Uppsala, Swedish.

Cooke, R.C. \& B.E.S. Godfrey. 1964. A key to nematodedestroying fungi. T. Brit. Mycol. Soc. 47: 61-74.

Delgado, A.E., A.J. Piñeiro \& L.M. Urdaneta. 2001. Hongos coprofílicos mitospóricos del Estado Zulia, Venezuela. (Downloaded: April 29, 2009, http:// redalyc.uaemex.mx/redalyc/src/inicio/ArtP dfRed. jsp?iCve $=61412202$ ).

Duddington, C.L. 1955. The friendly fungi: a new approach to the eelworm problem. Faber and Faber, London, United Kingdom.

Elósegui, O. 2006. Métodos artesanales de producción de bioplaguicidas a partir de hongos entomopatógenos y antagonistas (Downloaded: November 6, 2007, www.inisav.cu/OtrasPub/ METODOS\%20ARTESANALES $\% 20 D E \% 20$ PRODUCCI\%C3\%93N\%20 DE\%20BIOPLAGUICIDAS.pdf).

FAO (Food and Agriculture Organization). 2003. Resistencia a los antiparasitarios: estado actual con énfasis en América Latina. Dirección de Producción y Sanidad Animal de la FAO. Estudio FAO, Producción y Sanidad Animal 157, Rome, Italy.

Fleming, S.A., T. Craig, R.M. Kaplan, J.E. Miller, C. Navarre \& M. Rings. 2006. Anthelmintic resistance of gastrointestinal parasites in small ruminants. J. Vet. Intern. Med. 20: 435-444.

Flores, J., D. Herrera, P. Mendoza de Gives, E. Liébano, V.M. Vázquez \& M.E. López. 2003. The predatory capability of three nematophagous fungi in the control of Haemonchus contortus infective larvae in ovine faeces. J. Helminthol. 77: 297-303.

Gomes, A.P.S., M.L. Ramos, R.S. Vasconcellos, J.R. Jensen, M.C.R. Vieira \& J.V. Araújo. 2000. In vitro activity of brazilian strains of the predatory fungi Arthrobotrys spp. on free-living nematodes and infective larvae of Haemonchus placei. Mem. Inst. Oswaldo Cruz 95: 873-876.

González, R., P. Mendoza de Gives, G. Torres, C. Becerril, E. Ortega \& O. Hernández. 2005. Estudio in vitro de la capacidad depredadora de Duddingtonia flagrans contra larvas de nemátodos gastrointestinales de ovinos de pelo. Téc. Pecu. Méx. 43: 405-414.

Graminha, E.B.N., A.J. Costa, G.P. Oliveira, A.C. Monteiro \& S.B.S. Palmeira. 2005a. Biological control of sheep parasite nematodes by nematode-trapping fungi: in vitro activity and after passage through the gastrointestinal tract. World J. Microb. Biot. 21:717-722. 
Graminha, E.B.N., A.C. Monteiro, H.C. Silva, G. Pereira \& A.J. Costa. 2005b. Controle de nematóides parasitos gastrintestinais por Arthrobotrys musiformis em ovinos naturalmente infestados mantidos em pastagens. Pesq. Agropec. Bras. 40: 927-933.

Hajieghrari, B., M. Torabi, M.R. Mohammadi \& M. Davari. 2008. Biological potantial of some Iranian Trichoderma isolates in the control of soil borne plant pathogenic fungi. Afr. J. Biotechnol. 7: 967-972.

Haard, K. 1968. Taxonomic studies on the genus Arthrobotrys corda. Mycologia 60: 1140-1159.

InfoStat. 2002. InfoStat versión 1.1. Grupo InfoStat, FCA, Universidad Nacional de Córdoba, Córdoba, Argentina.

Kanda, S., T. Aimi, S. Kano, S. Ishihara, Y. Kitamoto \& T. Morinaga. 2008. Ambient $\mathrm{pH}$ signaling regulates expression of the serine protease gene (spr1) in pine wilt nematode-trapping fungus, Monacrosporium megalosporum. Microbiol. Res. 163: 63-72.

Kumar, D. \& K.P. Singh. 2006. Assessment of predacity and efficacy of Arthrobotrys dactyloides for biological control of root knot disease of tomato. J. Phytopathol. 154: 1-5.

Larsen, M. 2000. Prospects for controlling animal parasitic nematodes by predacious micro fungi. Parasitology 120: 121-131.

Li, Y., K.D. Hyde, R. Jeewon, L. Cai, D. Vijaykrishna \& K. Zhang. 2005. Phylogenetics and evolution of nematode-trapping fungi (Orbiliales) estimated from nuclear and protein coding genes. Mycologia 97: 1034-1046.

Madigan, M.T., J.M. Martinko \& J. Parker. 2000. Brock: Biología de los Microorganismos. Prentice Hall Iberia, Madrid, España.

Migunova, V.D \& B.A. Byzov. 2005. Determinants of trophic modes of the nematophagous fungus Arthrobotrys oligospora interacting with bacterivorous nematode Caenorhabditis elegans. Pedobiologia 49: 101- 108 .

Minglian, Z., M. Minghe \& Z. Keqin. 2004. Characterization of a neutral serine protease and its full-length cDNA from the nematode-trapping fungus Arthrobotrys oligospora. Mycologia 96: 16-22.

Morgan, M., J.M. Behnke, J.A. Lukas \& J.F. Peberdy. 1997. In vitro assessment of the influence of nutrition, temperature and larval density on trapping of the infective larvae of Heligmosomoides polygyrus by Arthrobotrys oligospora, Duddingtonia flagrans and Monacrosporium megalosporum. Parasitology 115: 303-310.

Mota, M.A., A.K. Campos \& J.V. Araújo. 2003. Controle biológico de helmintos parasitos de animais: estágio atual e perspectivas futuras. Pesq. Vet. Bras. 23: 93-100.

Nagee, A., A. Acharya, A. Shete, P.N. Mukhopadhyaya \& B.A. Aich. 2008. Molecular characterization of an expressed sequence tag representing the cuticle-degrading serine protease gene (PII) from the nematophagous fungus Arthrobotrys oviformis by differential display technology. Genet. Mol. Res. 7: 1200-1208.

Núñez, A.E. 2002. Aislamiento y evaluación de hongos nematófagos asociados a quistes de Globodera rostochiensis (Woll.) en la región del Cofre de Perote. Master thesis, Universidad de Colima, Colima, México.

Ojeda, N.F., P. Mendoza de Gives, J.F.J. Torres, R.I. Rodríguez \& A.J. Aguilar. 2005. Evaluating the effectiveness of a Mexican strain of Duddingtonia flagrans as a biological control agent against gastrointestinal nematodes in goat faeces. J. Helminthol. 79: 151-157.

Orozco, M. 2005. Aislamiento y caracterización de hongos nematófagos como potenciales controladores biológicos de nemátodos gastrointestinales para la producción animal. Tesis. Posgrado, Universidad Nacional, Heredia, Costa Rica.

Park, J.O., W. Gams, M. Scholler, E.L. Ghisalberti \& K. Sivasithamparam. 2002. Orbiliaceous nematode-trapping fungi and related species in Western Australia and their biological activities. Australasian Mycologist 21: 45-52.

Su, H., Y. Hao, M. Mo \& K. Zhang. 2007. The ecology of nematode-trapping hyphomycetes in cattle dung from three plateau pastures. Vet. Parasitol. 144: 293-298.

Tilly, J.M. \& R.A. Terry. 1963. A two-stage technique for the in vitro digestion of forage crops. J. Br. Grassl. Soc. 18: 104-111.

Tunlid, A. \& S. Jansson. 1991. Proteases and their involvement in the infection and immobilization of nematodes by the nematophagous fungus Arthrobotrys oligospora. App. Environ. Microb. 57: 2868-2872.

Van Oorschot, C.A.N. 1985. Taxonomy of the Dactylaria complex. A review of Arthrobotrys and allied genera. Stud. Mycol. 26: 61-96. 
Várady, M., P. Čudeková \& J. Čorba. 2007. In vitro detection of benzimidazole resistance in Haemonchus contortus: egg hatch test versus larval development test. Vet. Parasitol. 149: 104-110.

Vargas, C.F. 2006. FAMACHA®C Control de Haemonchosis en caprinos. Agronomía Mesoamericana 17: 79-88.
Villalba, V. 2006. Manual de laboratorio: Aspectos moleculares de la fitopatología. Ingeniería en Biotecnología, Escuela de Biología, Instituto Tecnológico de Costa Rica, Cartago, Costa Rica.

Zajac, A.M. \& G.A. Conboy. 2006. Veterinary Clinical Parasitology. Blackwell, New York, USA. 